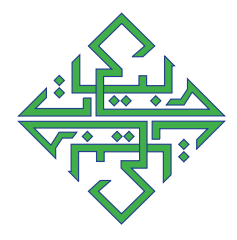

\title{
STANDARISASI KURIKULUM PENDIDIKAN BAHASA ARAB DI PERGURUAN TINGGI KEAGAMAAN ISLAM NEGERI
}

\author{
Muhbib Abdul Wahab \\ Universitas Islam Negeri Syarif Hidayatullah Jakarta \\ Email: muhbibwahab@gmail.com
}

Naskah diterima: 18 Februari 2016, direvisi: 12 Maret 2016, disetujui: 20 April 2016.

\begin{abstract}
This study aimed at assessing and analyzing the bases of the standardization of KKNI (Indonesian Qualification Framework)-based curricular development of Arabic language education. The method used in this study was a qualitative method based on text analysis. Therefore, the analysis that was used to read and interpret qualitative data is content and system analyses. This study concluded that the standardization of Arabic language education curriculum should ideally be developed integratively, holistically and humanistically. The standardization of KKNI and SNPT-based Arabic language curriculum should be developed as a multi-integrated system combined with four language skills plus study skills, theories of Arabic language education that are relevant to the development goals of the department, and the provision of real experience (e. g. live and interact with the Arab community) in a certain period of time in one of the Arab countries, while conducting a research and writing a scientific writing.
\end{abstract}

Keywords : standardization of curriculum, KKNI, Arabic language education

\section{Abstrak}

Studi ini bertujuan untuk mengkaji dan menganalisis pemikiran pengembangan kurikulum Pendidikan bahasa Arab (PBA) berbasis KKNI yang standar. Metode yang digunakan dalam studi ini adalah metode kualitatif berbasis analisis teks. Karena itu, analisis yang digunakan dalam membaca dan memaknai data kualitatif adalah analisis isi dan analisis sistem. Studi ini berkesimpulan bahwa standarisasi kurikulum Pendidikan Bahasa Arab idealnya dikembangkan secara integratif-holistik dan humanis. Standarisasi kurikulum bahasa Arab berbasis KKNI dan SNPT harus dikembangkan sebagai multi-sistem terpadu (integrated system), memadukan empat keterampilan bahasa plus keterampilan studi (study skills), ilmu-ilmu bahasa Arab yang relevan dengan tujuan pengembangan Prodi, dan pemberian pengalaman nyata (tinggal dan berinteraksi dengan komunitas Arab) dalam jangka waktu tertentu di salah satu Negara Arab, sambil riset dan menyusun skripsi.

Kata Kunci : standarisasi kurikulum, KKNI, pendidikan bahasa Arab

How to Cite : Abdul Wahab, Muhbib. "STANDARISASI KURIKULUM PENDIDIKAN BAHASA ARAB DI LINGKUNGAN PERGURUAN TINGGI KEAGAMAAN ISLAM NEGERI" Arabiyat : Jurnal Pendidikan Bahasa Arab dan Kebahasaaraban [Online], Volume 3 Number 1 (30 Juni 2016)

Permalink/DOI: http://dx.doi.org/10.15408/a.v3i1.3187 


\section{Pendahuluan}

Pengembangan kurikulum pendidikan bahasa Arab (PBA) menjadi sangat penting, baik penyusunan kurikulum bahasa yang baru sama sekali (curriculum construction), maupun penyempurnaan dan pengembangan kurikulum yang telah ada (curriculum improvement). Kurikulum pembelajaran bahasa di era globalisasi ini tentu lebih kompleks karena harus mempertimbangkan berbagai faktor dan varibel yang terkait dengan filsafat (hakikat dan fungsi) bahasa, aspek sosial budaya, psikologi siswa yang belajar bahasa, lingkungan sosial politik, sistem pendidikan dan pembelajaran, dan sebagainya.

Pengembangan kurikulum, termasuk standarisasi kurikulum PBA, diyakini sebagai langkah strategis dalam rangka pengembangan dan peningkatan mutu pendidikan itu sendiri. Berdasarkan sejumlah penelitian, pengembangan kurikulum itu idealnya diorientasikan kepada pemenuhan tuntutan pembangunan dan untuk merespon tantangan globalisasi, dengan tetap mempertimbangkan proporsionalitas antara dimensi kuantitas dan kualitas pembelajaran sesuai dengan standar-standar yang dirumuskan. ${ }^{1}$

Penelitian Yun Eun Kyeong (2012) menyimpulkan bahwa kurikulum pembelajaran bahasa Arab yang paling utama adalah kurikulum yang dapat memadukan metode pembelajaran yang komprehensif, yang mengintergrasikan antara bahasa Arab fush $\underline{h} \hat{a}$ dan 'âmiyyah (fush $\underline{h a}$ modern, 'âmiyyah para cendekiawan dan dialek 'âmiyyah), sekaligus menawarkan materi

Abd as-Salam Musthafa Abd as-Salam, “Tathwîr Manâhij at-Ta'lîm li Talbiyat Mutathallabât at-Tanmiyah wa Muwâjahat Tahaddiyatal-'Awlamah" dalam Prosiding Mu'tamar at-Ta'lîm an-Nau'î wa Dawruhu fi at-Tanmiyah al-Basyariyyah fi 'Ashr al'Awlamah, Jami'ah al-Manshûrah Mesir, 2006, h. 272. pembelajaran beragam yang dalam memenuhi keinginan pembelajar, sekaligus dalam meningkatkan empat keterampilan berbahasa secara efektif. ${ }^{2}$

Gagasan pengembangan kurikulum Pendidikan Bahasa Arab idealnya berbasis visi pengembangan keilmuan dan pembelajaran agar produk kurikulum yang dirumuskan dapat merespon tantangan zaman. Musthafa Abd as-Sami' Muhammad memandang penting pengembangan kurikulum itu memperhatikan empat hal: prospektif, prosedur, proses, dan progres yang akan diaktualisasikan. Strategi pengembangan kurikulum bahasa Arab menekankan pengembangan kompetensi komunikasi aktif (active communication), sedapat mungkin ditunjang program CALL (Computer Assisted Learning Language), dengan teknik 4R (Reuducation, Responsibility, Relevance, Rapport) dalam proses pembelajarannya, sehingga pengembangan kurikulum itu dapat memberikan jaminan mutu dalam proses dan produk pembelajarannya. ${ }^{3}$

Dalam rangka memperkaya pemikiran tentang kurikulum berbasis KKNI (Kerangka Kualifikasi Nasional Indonesia) dan SNPT (Standar Nasional Pendidikan Tinggi), kajian ini bertujuan untuk mendiskusikan standarisasi pengembangan kurikulum pendidikan bahasa Arab di masa depan. Sejumlah pertanyaan akademik akan didiskusikan dengan pendekatan kualitatif berbasis analisis teks, yaitu: (1) Atas dasar apa(landasan)kurikulumpendidikanbahasa

2 Yun Eun Kyeong, “Afdhal Manhaj Ta’lim al-Lughah al-Arabiyyah li Ghair an-Nathiqina biha min Wijhat Nazhar 'Ilm al-Lughah al-Ijtima'I', dalam Journal al-Ustâdz (Majallah al-Ustâdz), Edisi 201, Tahun 2012, h. 99

3 Musthafa 'Abd as-Sami' Muhammad, "Dhamanat Tathwir Manahij al-Lughah al-'Arabiyyah: Ru'yah Mustaqbaliyyah", dalam Majallah al-Lisan alArabi, Edisi 3, 2010. 
Arab dikembangkan, terutama berbasis KKNI dan SNPT? (2) Diorientasikan ke mana pengembangan kurikulum pendidikan bahasa Arab di lingkungan PTKIN (UIN, IAIN, dan STAIN) ke depan? (3) Bagaimana mendesain kurikulum pendidikan bahasa Arab, khususnya standar kompetensi calon lulusan, yang kompatibel dengan tuntutan globalisasi dewasa ini?

\section{Peta Orientasi Pendidikan Bahasa Arab}

Selama ini, sebagai peminat kajian, penstudi dan/atau praktisi pendidikan bahasa Arab, kita pada umumnya baru sekadar memposisikan bahasa Arab sebagai alat (wasîlah) -untuk memahami teks keislamanyang berbahasaArab—dan belum sepenuhnya memfungsikannya sebagai disiplin ilmu yang perlu dikembangkan melalui riset/penelitian, pengkajian dan pembacaan kembali secara kritis dan mendalam. Pandangan kita terhadap bahasa Arab selama ini boleh jadi juga masih terpengaruh pendapat ulama masa lalu bahwa bahasa Arab itu -khususnya nahwu dan sharaf-telah "matang dan terbakar"4, dalam arti bahwa ilmu ini sudah

4 Amîn al-Khûlî mengelompokkan Ilmu bahasa Arab tradisional menjadi tiga, yaitu: (1) 'ilm nadhija wa ihtaraqa (ilmu yang sudah matang dan terbakar), seperti ilmu nahwu dan ilmu kalam (teologi), (2) 'ilm la nadhija wa la ihtaraqa (ilmu yang tidak matang dan tidak terbakar), seperti tafsir dan 'ilm al-bayân; dan (3) 'ilm nadhija wa ma ihtaraqa (ilmu yang sudah matang tetapi tidak terbakar), seperti: fiqh dan hadits. Lihat Amîn alKhûlî, Manâhij al-Tajdîd fi al-Nahnwi wa al-Balâghah wa al-Tafsîr wa al-Adab, (Kairo: Dâr al-Ma'ârif, 1961), Cet. I, h. 127. Pendapat bahwa nahwu itu sudah "matang dan selesai" dibantah oleh Tammâm Hassân. Menurutnya, nahwu sebagai ilmu tetap berkembang, bergantung pada perspektif dan metode penelitian yang digunakan. Metode deskriptif dari linguistik modern cukup kompatibel untuk dijadikan sebagai media untuk melihat ulang (i'âdah al-nazhar) dan mengembangkan nahwu dan ilmu-ilmu bahasa Arab lainnya. Lihat Tammâm Hassân, al-Lughah al'Arabiyyah: Ma'nâhâ wa Ma'nâhâ, (Kairo: al-Haiah final, tidak mungkin lagi dikembangkan dan diperbarui.

Fakta menunjukkan bahwa bahasa Arab (PBA) di Indonesia telah diajarkan mulai dari TK (sebagian TK Islam) hingga Perguruan Tinggi. Berbagai potret penyelenggaraan PBA di lembaga-lembaga pendidikan Islam setidak-tidaknya menunjukkan adanya upaya serius untuk memajukan sistem dan mutunya. Geliat yang sangat dinamis di kalangan akademisi muda, antara lain seperti di UIN Maliki Malang dan UIN Syarif Hidayatullah Jakarta dengan berbagai karyanya tentang PBA yang telah dipublikasikan, membuktikan bahwa PBA di tanah air masih dan akan terus memberikan prospek yang cerah di masa depan.

Secara empirik, paling tidak ada empat orientasi pendidikan bahasa Arab. Pemetaan orientasi berikut menjadi sangat penting untuk memposisikan dan menentukan arah pengembangan kurikulum PBA ke depan. Pertama, orientasi religius, yaitu belajar bahasa Arab untuk tujuan memahami dan memahamkan ajaran Islam (fahm almaqrû'). Orientasi ini terlihat pada belajar dan pembelajaran keterampilan reseptif/ mahârah istiqbâliyyah (menyimak dan membaca), dan terlihat pula pada belajar al-Mishriyyah al-'Ammah li al-Kitâb, 1985), Cet. III, h. 7. Dalam Ijtihâdât Lughawiyyah, Tammâm menyerukan pentingnya ijtihad dalam pemikiran bahasa Arab, karena pemikiran linguistik Arab banyak terkungkung oleh sejarahnya itu sendiri, di samping karena kurangnya daya kritis dari para ulama bahasa Arab kontemporer terhadap warisan intelektual Arab klasik. Bahkan hegemoni nahwu historis (al-nahwwu al-târîkhî) itu jauh lebih kuat dibandingkan dengan perkembangan pengetahuan. Warisan pemikiran nahwu yang telah menyejarah itu, dengan aneka perbedaan pendapat dan aliran yang ada berikut tokoh-tokohnya, lebih banyak diwacanakan daripada substansi keilmuan nahwu itu sendiri. Lihat Tammâm Hassân, Ijtihâdât Lughawiyyah, (Kairo: 'Âlam al-Kutub, 2007); dan 'Abd al-Salâm al-Musaddî, "al-Lughah al-'Arabiyyah wa al-Tahaddiyât al-Jadîdah", diakses dari http://www. alriyadh.com/2005/05/12/article, 30 Juni 2013. 
dan pempelajaran keterampilan ekspresifproduktif/mahârah ta'bîriyyah-intâjiyyah (berbicara dan menulis). ${ }^{5}$

Kedua, orientasi akademik, yaitu belajar bahasa Arab untuk tujuan memahami ilmu-ilmu dan keterampilan berbahasa Arab (istimâ', kalâm/tahadduts, qirâ'ah, dan kitâbah) plus terjemah. Orientasi ini menempatkan bahasa Arab sebagai disiplin ilmu atau objek studi yang harus dikuasai secara akademik. Orientasi ini biasanya identik dengan studi bahasa Arab di Jurusan Pendidikan bahasa Arab, Bahasa dan Sastra Arab, atau pada program Pascasarjana dan lembaga ilmiah lainnya.

Ketiga, orientasi profesional/praktis dan pragmatis, yaitu belajar bahasa Arab untuk tujuan dan kepentingan profesi, praktis atau pragmatis, seperti belajar bahasa Arab untuk tujuan mampu berkomunikasi lisan (muhâdatsah) dalam bahasa Arab untuk bisa menjadi TKI, diplomat, turis, pebisnis, atau untuk melanjutkan studi di salah satu negara Timur Tengah, dan sebagainya.

Keempat, orientasi ideologis dan ekonomis, yaitu belajar bahasa Arab untuk memahami dan menggunaakan bahasa Arab sebagai media bagi kepentingan orientalisme, kapitalisme, imperialisme, dan sebagainya. Orientasi ini, antara lain, terlihat dari dibukanya beberapa lembaga kursus dan institusi studi bahasa Arab di negara-negara Barat, seperti Ma'had alDirâsât al-Syarqiyyah di Universitas Leipzig Jerman. ${ }^{6}$

5 Kedua istilah keterampilan tersebut digunakan oleh Rusydi Ahmad Thu'aimah dalam melihat pentingnya kesatupaduan dalam pengembangan keterampilan berbahasa. Lihat Rusydi Ahmad Thu'aimah, Manahij Tadris al-Lughah al-'Arabiyyah bi al-Ta'lim al-Asasi, (Kairo: Dar al-Fikr al-'Arabi, 2001), h.28-29.

6 Muhbib Abdul Wahab, "Quo Vadis Pendidikan Bahasa Arab di Era Globalisasi", Makalah disampaikan dalam Seminar Sehari BEMJ PBA FITK UIN Jakarta, 29 Mei 2006; dan Muhbib Abdul

\section{Epistemologi Pengembangan Ilmu Kebahasaaraban}

Epistemologi merupakan salah
satu cabang dari filsafat ilmu ${ }^{7}$ yang membahas bagaimana ilmu diperoleh, dibangun, dan dikonseptualisasikan. Epistemologi disebut juga teori pengetuhuan (nazhariyyat al-ma'rifah), yaitu teori tentang asal-usul, sumber, cara pemerolehan, kerangka metodologis, dan bangunan ilmu pengetahuan. Jika ontologi mempertanyakan apa yang dikaji oleh sebuah ilmu; aksiologi mempermasalahkan untuk apa ilmu digunakan dalam kehidupan, maka epistemologi mengkritisi bagaimana ilmu itu diperoleh dan dikembangkan dalam suatu bingkai atau bangunan pengetahuan yang utuh, sistematis, integratif dan interkonektif. Tanpa epistemologi sebuah ilmu menjadi tidak jelas landasarn keilmuan, akar historis, objek formal dan material berikut substansi kajiannya, dan kerangka metodologisnya.

Epistemologi mengkaji dan mengkritisi status suatu bidang keilmuan. Hal ini

Wahab, Epistemologi dan Metodologi Pembelajaran Bahasa Arab, (Jakarta: UIN Jakarta Press, 2008), h. 105-6.

Dua cabang filsafat ilmu lainnya adalah ontologi dan aksiologi. Ontologi membicarakan isi ilmu; sedangkan aksiologi membahas nilai atau etika penggunaan ilmu. Epistemologi (dari bahasa Yunani episteme (pengetahuan) dan logos (kata/ pembicaraan, teori) adalah cabang filsafat yang berkaitan dengan asal, sifat, dan jenis pengetahuan. Topik ini termasuk salah satu yang paling sering diperdebatkan dan dibahas dalam bidang filsafat, misalnya tentang apa itu pengetahuan, bagaimana karakteristik, kategori, serta hubungannya dengan kebenaran dan keyakinan. Lihat Sami Muhammad Mulham, Manâhij al-Bahts fi al-Tarbiyah wa 'Ilm al-Nafs, ('Amman: Dâr al-Masîrah, 2002), h. 27-40. Epistemologi juga membahas: sources, nature, and limits of knowledge (sumber, watak/ karakter, dan batas-batas pengetahuan). Lihat J. Dancy, Introduction to Contemporary Epistemology (1985). 
penting dilakukan karena tiga alasan yang saling berkait. Pertama, fungsi utama ilmu adalah menjelaskan (explaining) ${ }^{8}$. Sebuah ilmu dikatakan dapat berfungsi jika dapat menjelaskan dengan lugas dan sistematis status ilmu itu sendiri dan objek yang dipelajarinya. Ilmu bahasa Arab, misalnya, dapat dianggap sah sebagai ilmu jika bangunan ilmu ini dapat menjelaskan status keilmuannya di satu pihak, dan objek kajian atau materi dan substansi yang menjadi wilayah studinya. Dengan kata lain, epistemologi mengantarkan kita kepada bagaimana seharusnya sebuah "sosok dan bangunan ilmu" itu dipahami: mengapa dan bagaimana ilmu itu dapat dikonseptualisasikan secara logis, metodis, dan sistematis? Mempertanyakan status keilmuan tidak hanya penting untuk mengetahui "profil ilmu", tetapi juga dapat menyikapi bagaimana seharusnya ilmu kebahasaaraban itu, termasuk kurikulum PBA, dikembangkan.

Kedua, sifat ilmu adalah dinamis, akumulatif, dan logis. Ilmu tidak lahir dan langsung besar, matang dan kaya (informasi dan teori). Ilmu berkembang secara bertahap dan berkelanjutan. Ilmu dibangun dengan logika keilmuan: berpikir rasional, sistematis dan metodologis. Epistemologi bahasa Arab perlu direvitalisasi agar kita tidak terjebak dalam pola pikir yang cenderung "membunuh kreativitas dan produktivitas" bahwailmuini sudah matang -bahkan sudah terbakar dan hangus (qad nadhija wa ihtaraqa) - sehingga tidak lagi ada ruang untuk dikembangkan. Sesuai

\footnotetext{
$8 \quad$ Fungsi ilmu lainnya adalah: mendeskripsikan, memahami fenomena dan obyek yang menjadi kajian ilmu, memprediksi (meramalkan) sesuatu yang mungkin terjadi, dan mengontrol atau mengendalikan peristiwa-peristiwa yang akan terjadi agar tidak menimbulkan dampak negatif yang jauh lebih besar. Lihat, antara lain, Sâmî Muhammad Mulham, Manâhij al-Bahts fi al-Tarbiyah ...., h. 29-31.
}

dengan karakter ilmu yang cenderung progresif (berkembang dinamis dan akumulatif), ilmu bahasa Arab idealnya juga tidak stagnan, melainkan terus berkembang dan menjadi maju. Yang masih menjadi persoalan adalah sudah sampai mana dinamika dan progresivitas ilmu-ilmu bahasa Arab ini dikembangkan? Dalam konteks ini, barangkali diperlukan diskusi tersendiri.

Ketiga, arah pengembangan keilmuan bahasa Arab di masa depan perlu diletakkan padalandasan epistemologisnya secara kokoh dan benar. Kesulitan besar akan dialami dalam mengkaji dan mengembangkan suatu disiplin ilmu jika tidak diketahui dasar-dasar epistemologis ilmuitu.Demikian pula, pengembanganilmu bahasa Arab akan mengalami disorientasi apabila sejarah perkembangan, landasan epistemologi, dan kerangka metodologi ilmu bahasa Arab tidak dipahami secara memadai.

Sedemikian pentingnya epistemologi ilmu-ilmu bahasa Arab, sehingga Tammâm Hassân merevitaliasi pengokohan basis kajian linguistiknya dengan terlebih dahulu memantapkan fondasi keilmuannya dengan menulis karya Manâhij al-Bahts fi al-Lughah, al-Lughah baina al-Mi'yâriyyah wa al-Washfiyyah, dan al-Ushûl. Meskipun difokuskan pada tiga bidang ilmu, yaitu: nahwu, fiqh al-lughah dan balâghah, karya yang terakhir dipandang relevan untuk dijadikan sebagai basis pengembangan ilmu-ilmu bahasa Arab pada umumnya9.

9 Menurut Tammâm, nahwwu hingga saat ini "belum selesai": masih berkembang, dan karena itu, perlu dikembangkan. Dalam hal ini, Tammâm mengembangkanmodelbaruklasifikasikatamenjadi tujuh, karena klasifikasi kata menjadi tiga (ism, fi'l, harf) dinilai tidak jelas batasan-batasan dan dasardasar epistemologisnya. Demikian pula, ia juga mengkritisi -sebagaimana ahli nahwu lainnyasalah satu qarînah yang selama ini menyibukkan para ahli nahwu, yaitu qarînah al-i'râb. Ia kemudian 
Melalui ketiga karya tersebut, pengkaji bahasa Arab dapat memahami "peta keilmuan" bahasa Arab dengan jelas dan distingtif, sehingga pengembangan kurikulum ${ }^{10}$ pendidikan dan pembelajaran bahasa Arab dapat dilakukan sesuai dengan kebutuhan, tuntutan keilmuan, dan perkembangan zaman, termasuk pengembangannya berbasis KKNI.

\section{Landasan Pengembangan Kurikulum PBA}

Kurikulum (manhaj) merupakan "jantung" institusi pendidikan atau sistem pembelajaran. Tanpa kurikulum proses pembelajaran bahasa Arab mengenalkan dan menganggap penting sinergi atau pemaduan berbagai indikator/qarâin (al-binyah, al-shîghah, al-rutbah, al-tadhâmm, al-rabth, alsiyâq, al-naghmah atau al-tanghîm) dan qarâin ma'nawiyyah dalam pemaknaan kalimat. I'râb saja tidak cukup untuk memahami kalimat, karena tidak semua kata dalam kalimat itu memperlihatkan i'râb yang semestinya. Para ahli nahwu klasik cenderung "terfokus" pada konsep kala (waktu) yang hanya terbatas pada al-zaman al-sharfî. Menurutnya, konsep tenses (al-zaman al-nahwî) dapat dikembangkan sesuai konteks, karena nahwu merupakan jaringan relasi kontekstual (syabakah min al-'alâqât al-siyâqiyyah) yang setiap relasi itu menempati posisinya dalam konteks kalimat dalam memperjelas makna. Tammâm, Ijtihâdât ..., h. 90; dan Tammâm, al-Lughah al-'Arabiyyah ..., h. 242247.

10 Kurikulum itu merupakan seperangkat pengalaman dan program pendidikan yang terencana yang didesain dan diberikan oleh institusi pendidikan kepada peserta didik dengan tujuan membantu mereka tumbuh dan berkembang secara terpadu (fisik, mental, intelektual, emosional, spiritual, sosial, dan sebagainya), sehingga mampu beradaptasi dan berkreasi dalam menghadapi berbagai persoalan kehidupan mereka. Dengan demikian, kurikulum pembelajaran bahasa Arab tidakhanya berisi struktur mata pelajaran/kuliah, melainkan juga mengandung rancang bangun program dan pengalaman yang hendak diaktualisasikan pada diri peserta didik sesuai dengan standar kompetensi dan performansi lulusan yang telah dirumuskan. Lihat Hasan Ja'far al-Khalifah, al-Manhaj al-Madrasî al-Mu'âshir: alMafhûm, al-Usus, al-Mukawwinât, al-Tanzhîmât, (Riyadh: Maktabah al-Rusyd, 2003), h.20. menjadi tidak jelas arah dan orientasinya. Kurikulum (curriculum, al-manhaj), yang secara bahasa berarti jalan yang jelas, tidak hanya berupa struktur mata pelajaran dan silabus, melainkan keseluruhan pengetahuan, keterampilan, pengalaman, dan kepribadian yang akan ditransformasikan melalui proses pendidikan, sehingga peserta didik mengalami perkembangan dan kemajuan ke arah terbentuknya pribadi yang berpikir rasional, berpengetahuan luas, bersikap positif, berketerampilan dan berkepribadian sosial. ${ }^{11}$

Kurikulum pembelajaran bahasa Arab menjadisangatpentinguntukdikembangkan agar proses pembelajarannya menjadi lebih bermutu, mengikuti perkembangan keilmuan (relevansi intelektual) dan kebutuhan masyarakat, serta output yang dihasilkan sesuai dengan tuntutan pasar (relevansi sosial). Demikian pula, ilmu-ilmu bahasa Arab pada umumnya juga berwatak dinamis dan progresif. Dengan pengembangan kurikulum, tujuan pembelajaran, isi (content), metode, media, interaksi, dan evaluasi pembelajaran pembelajaran bahasa menjadi jelas, terarah, dan terukur. ${ }^{12}$

Menurut Rusydi Ahmad Thu'aimah, setidak-tidaknya ada empat landasan yang menjadi dasar pengembangan kurikulum, yaitu landasan linguistik, landasan edukatif, landasan psikologis, dan landasan sosial. Landasan kebahasaan berkaitan dengan perlunya dipertimbangkan konsep, perspektif, filsafat, dan karakteristik bahasa Arab. Aspek-aspek mendasar

11 'Imran Jasim al-Jabburi dan Hamzah Hasyim as-Sulthani, al-Manâhij wa Tharâ'iq Tadrîs al-Lughah al-'Arabiyyah, ('Amman: Muassasah Dâr al-Shâdiq asTsaqâfiyyah, 2013), h. 21.

12 'Ali Ismail Muhammad, al-Manhaj fi alLughah al-Arabiyyah, (Kairo: Maktabah Wahbah, 1997), h. 78-80. 
berkaitan dengan bahasa, seperti: (1) bahasa itu symbol, (2) bahasa itu bunyi, (3) bahasa itu sistem, (4) bahasa itu kebiasaan, (5) bahasa itu komunikasi, (6) bahasa itu konteks, dan (7) bahasa itu budaya, sangat menentukan corak pengembangan kurikulum bahasa Arab. ${ }^{13}$ Selain itu, pengembangan kurikulum bahasa Arab juga didasarkan pada landasan kognitif yang terkait dengan karakter, sumber, dan nilai ilmu pengetahuan dalam masyarakat berikut kebudayaannya. ${ }^{14}$

Selain itu, pandangan atau perspektif bahwa bahasa itu merupakan satu kesatuan yang utuh antara (1) lafazh dan makna atau mabnâ dan ma'nâ, (2) empat keterampilan (maharah/funun) kebahasaan, (3) bunyi, mufradât, dan tarâkib, (4) nahwwu, sharaf, uslûb dan balaghah, (5) maqâl dan maqâm (teks dan konteks) juga memberikan arah dan orientasi yang jelas dalam pengembangan kurikulum pembelajaran bahasa. Yang juga tidak kalah penting dipertimbangkan adalah karakteristik bahasa Arab ketika hendak dikurikulumkan dan dibelajarkan, bahwa bahasa Arab itu: bahasa derivasi (lughat istiqâq), bahasa i'râb (infleksi), bahasa kaya bunyi, bahasa tashrîf, bahasa yang kaya konstruksi kata (shiyagh), bahasa yang kaya ekspresi, gaya bahasa, konsep kala (waktu), dan sebagainya. ${ }^{15}$

Landasan edukatif terkait erat dengan sistem dan strategi pembelajaran. Pengembangan kurikulum harus mempertimbangkan penyusunan silabi,

13 Rusydi Ahmad Thu'aimah, Manahij Tadris..., h. 20 dan 27-29.

14 Rusydi Ahmad Thu'aimah, Ali Ahmad Madkur, dan Iman Ahmad Haridi, al-Marji' fi Manâhij Ta'lîm al-Lughah al-'Arabiyyah li an-Nâthiqîn bi Lughât Ukhrâ, (Kairo: Dâr al-Fikr al-'Arabî, 2010), h. 9.

15 Rusydi Ahmad Thu'aimah, Manahij Tadris..., h. 20 dan 30-32. materi ajar, perencanaan dan strategi pembelajaran yang membuat tujuan pembelajaran itu dapat tercapai dengan efektif. Penetapan metode yang fleksibel, media yang efektif, penciptaan suasana dan lingkungan pembelajaran bahasa yang kondusif juga penting dipertimbangkan dalam pengembangan kurikulum pembelajaran bahasa. Demikian pula landasan psikologis yang berkaitan dengan potensi, kemampuan, kebutuhan, minat, bakat, kecenderungan, motivasi, perbedaan individual, perasaan, emosi, dan kejiwaan peserta didik. Pengembangan Kurikulum pembelajaran bahasa Arab dapat dinilai efektif, berdayaguna, dan prospektifapabila dapat memenuhi kebutuhan psikologis dan memberi kepuasan batin peserta didik dalam belajar. Oleh karena itu, munculnya konsep joyful learning, active learning, collaborative learning, lesson study, CTL, constructivism learning, dan sebagainya merupakan pengembangan efektivitas pembelajaran bahasa.

Selain itu, landasan sosial budaya dalam pengembangan kurikulum juga menghendaki pentingnya mempertimbangkan perubahan sosial budaya, sosial ekonomi, sosial politik, adat-istiadat Islam, dan isu-isu aktual yang melingkupi sistem pembelajaran bahasa, sehingga bahasa sebagai alat komunikasi dapat dioptimalisasikan fungsi-fungsinya, baik fungsi instrumental, fungsi regulatori, fungsi interaktif, fungsi personal, fungsi heuristik, fungsi imajinatif, dan fungsi representasional, ${ }^{16}$ fungsi spiritual, dan fungsi permainan. ${ }^{17}$ Dengan demikian,

16 'Rusydi Ahmad Thu'aimah, Ta'lim alArabiyyah li Ghair al-Nâthiqîna binâ Manahijuhu wa Asalibuhu, (Rabath: Isesco, 1989), h. 119.

17 Rusydi Ahmad Thu'aimah dan Mahmud Kamil an-Naqah, Ta'lîm al-Lughah Ittishâliyyan: Baina al-Manâhij wa al-Istirâtijiyyât, (Rabath: Mansyûrât Isesco, 2006), h. 27. 
kurikulum pendidikan bahasa Arab berbasis KKNI juga harus tetap dilandasi oleh berbagai pertimbangan dan argumen linguistik, edukatif, psikologi, sosial budaya, dan -jika mau ditambahkan-teknologi dan manajemen pendidikan, sehingga kualitas pembelajaran bahasa Arab menjadi lebih bermutu, menyenangkan, dan membisakan.

\section{Bangunan dan Kompetensi Keilmuan PBA}

Pada masa kodifikasi ilmu-ilmu bahasa Arab (masa klasik) ditemukan bahwa pemetaan wacana studi kebahasaaraban membuktikan bahwa pada masa itu telah terbentuk sekurang-kurangnya delapan wacana dan tema sentral studi kebahasaaraban. Kedelapan tema sentral itu membentuk sebuah taksonomi dan hirarki sebagai berikut: (1) Naḩwu \& Sharaf, (2) Ushûl al-Nahwwî, (3) Fiqh al-Lughah, (4) Ma'âjim al-Lughah al'Arabiyyah, (5) 'ilm al-Arûdh, (6) Thabaqât al-Lughawiyyîn wa al-Nahwiyyîn, (7) alNaqd wa al-Balâghah, dan (8) al-Dirâsat al-Adabiyyah. Pemetaan ini memang baru didasarkan atas kecenderungan umum wacana yang berkembang saat itu. Namun demikian, menarik dicatat bahwa masing-masing tema tersebut terdapat berbagai sumber literatur dan para tokoh pengembangnya. Dengan kata lain, peta studi dan kurikulum bahasa Arab sangat terkait dengan wacana dan karya kebahasaaraban yang dikembangkan sesuai dengan konteks sosial budaya dan zamannya.

Menurut Sa'îd al-Afghânî (19091997), 'Ulûm al-Adab (ilmu sastra, dalam pengertian ilmu sebagai produk budaya manusia) itu ada enam, yaitu: 'ilm al- lughah (linguistik), nahwu, sharf, 'ilm alma'ânî, 'ilm al-bayân, dan 'ilm al-badî'. ${ }^{18}$ Jika disederhanakan, klasifikasi ini akan membentuk taksonomi ilmu bahasa Arab ke dalam empat bidang, yaitu: linguistik, nahwwu, sharaf dan balâghah. Dalam kerangka metodologisnya, Tammâm berusaha membuat distingsi antara shinâ'ah dan ma'arifah. Nahwu (termasuk sharaf) dan balâghah (yang obyek kajiannya adalah relasi antara uslûb dan makna) termasuk shinâ'ah (ilmu yang diperoleh melalui latihan/pembisaan dan membahas tsawâbit atau norma-norma baku/kaidah-kaidah). Sedangkan fiqh allughah termasuk kategori ma'rifah (ilmu yang diperoleh tanpa persyaratan latihan dan membahas mutaghayyirât, mutûn al-lughah kata-kata tunggal, relasi lafazh dengan lafazh, dan lafazh dengan makna, dan lafazh dengan penggunaannya). ${ }^{19}$

Dari penelusuran terhadap sumbersumber tersebut dan berdasarkan perkembangan yang terjadi di dunia keilmuan bahasa Arab, penulis memperoleh titik temu bahwa taksonomi dan hirarki ilmu bahasa Arab secara umum dapat dipetakan sebagai berikut:

\footnotetext{
18 Sa'îd al-Afghânî, Min Ushûl.. h. 17.

19 Tammâm, al-Ushûl ..., h. 243, 279 dan 285.
} 
Arabiyât Jurnal Pendidikan Bahasa Arab dan Kebahasaaraban, 3 (1), 2016

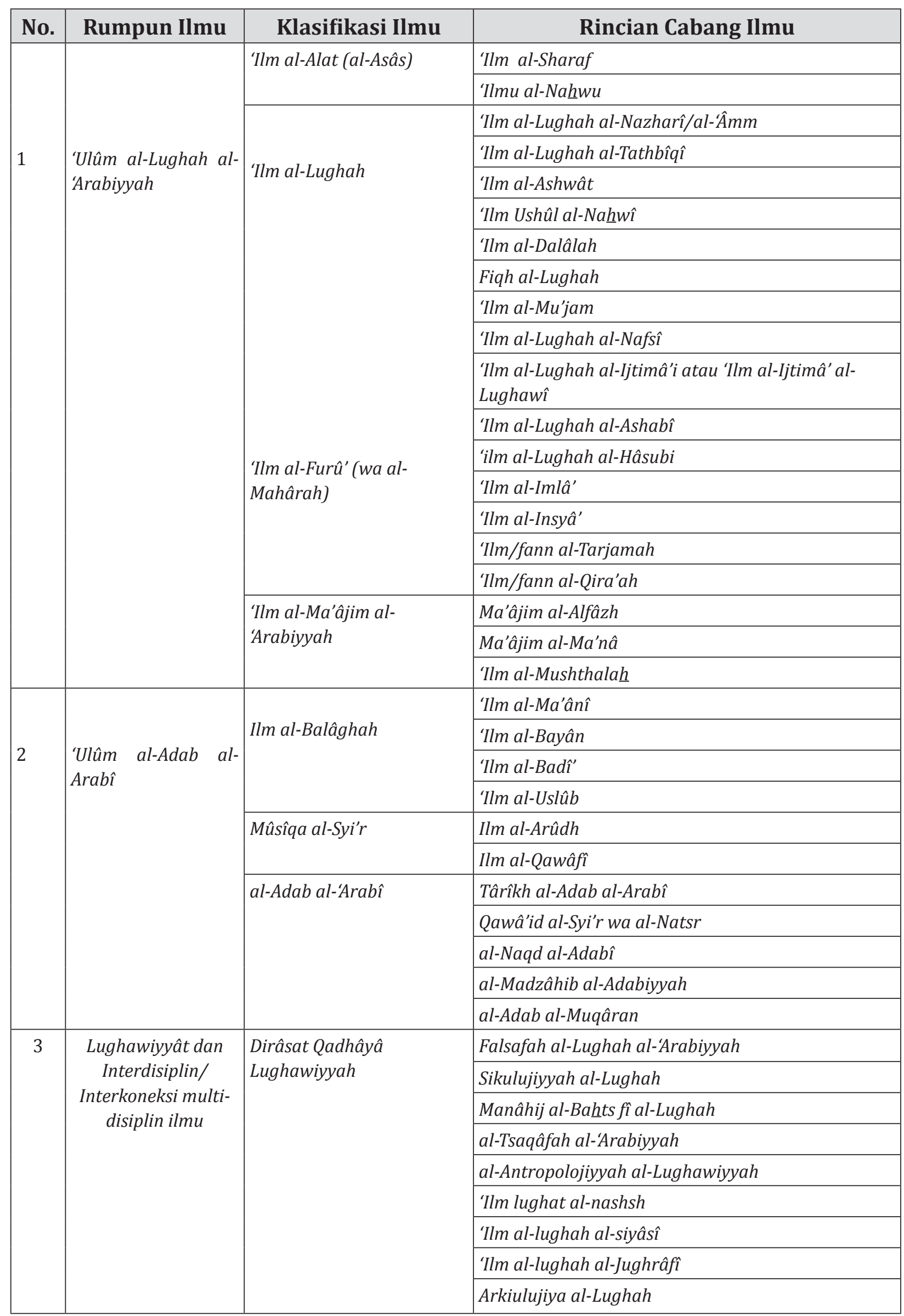


Jika kita menyepakati pendapat Abdurrahman bin Ibrahim al-Fauzan et.al (2005) bahwa unsur bahasa (Arab) itu ada tiga: ashwât (bunyi), mufradât (kosakata), dan struktur (tarâkîb), dan pembelajaran bahasa itu idealnya dapat mewujudkan tiga kompetensi, yaitu: kompetensi linguistik, komunikatif, dan sosio-kultural ${ }^{20}$ dan juga berdasarkan kerangka keilmuan bahasa Arab tersebut di atas yang kemudian dikaitkan dengan pembelajaran bahasa, maka -menurut penulis - standarisasi pengembangan kurikulum pembelajaran bahasa Arab berbasis KKNI dan SNPT ini dapat dikembangkan sebagai berikut.

\begin{tabular}{|c|c|c|c|}
\hline No. & $\begin{array}{c}\text { Unsur Bahasa, } \\
\text { Kompetensi, \& } \\
\text { Substansi Keilmuan }\end{array}$ & Standar Kompetensi & $\begin{array}{l}\text { Mata Kuliah yang bisa } \\
\text { Dikembangkan }\end{array}$ \\
\hline \multirow{2}{*}{1} & \multirow{2}{*}{ Ashwât (Bunyi Bahasa) } & \multirow{2}{*}{$\begin{array}{l}\text { Mampu menguasai bunyi- } \\
\text { bunyi bahasa Arab standar }\end{array}$} & Ilm al-Ashwât (Fonologi) \\
\hline & & & Lahajât Arabiyyah \\
\hline \multirow{3}{*}{2} & \multirow{3}{*}{ Mufradât } & \multirow{3}{*}{$\begin{array}{l}\text { Mampu menguasai kosakata } \\
\text { Arab dan menggunakannya } \\
\text { dalam kegiatan berbahasa, } \\
\text { termasuk membuat kamus }\end{array}$} & Mufradât wa ibarât ishtilâhiyyah \\
\hline & & & Ilm dan shinâ'at al-Mu'jam \\
\hline & & & Fiqh al-Lughah \\
\hline \multirow{3}{*}{3} & \multirow{3}{*}{ Tarâkib } & \multirow{3}{*}{$\begin{array}{l}\text { Mampu menguasai tarakib } \\
\text { dan menggunakannya dalam } \\
\text { kegiatan berbahasa }\end{array}$} & Sharaf \\
\hline & & & Nahwu \\
\hline & & & Balâghah \\
\hline \multirow{5}{*}{4} & \multirow{5}{*}{ Kompetensi Linguistik } & \multirow{5}{*}{$\begin{array}{l}\text { Mampu menguasai empat } \\
\text { keterampilan bahasa secara } \\
\text { proporsional, termasuk } \\
\text { keterampilan puncaknya, } \\
\text { yaitu Tarjamah. }\end{array}$} & Istimấ \\
\hline & & & Kalâm (Muhadatsah) \\
\hline & & & Qirâ'ah \\
\hline & & & $\begin{array}{l}\text { Kitâbah (Meliputi: Insya', Imlâ' dan } \\
\text { Khath) }\end{array}$ \\
\hline & & & Tarjamah \\
\hline \multirow{3}{*}{5} & \multirow{3}{*}{$\begin{array}{l}\text { Kompetensi } \\
\text { Komunikatif }\end{array}$} & \multirow{3}{*}{$\begin{array}{l}\text { Mampu berkomunikasi lisan } \\
\text { dan tulisan dengan native } \\
\text { speaker (an-nathiq bi al- } \\
\text { 'arabiyyah) dengan lancar }\end{array}$} & $\begin{array}{l}\text { Mumarasah Lughawiyyah } \\
\text { (Praktikum Bahasa, antara } \\
\text { lain: muhadatsah, munazharah, } \\
\text { masrahiyyah) }\end{array}$ \\
\hline & & & $\begin{array}{l}\text { Khibrah Wâqi'iyyah wa Dirasah } \\
\text { Maidaniyyah (Tinggal di salah satu } \\
\text { semester di negara Timteng) }\end{array}$ \\
\hline & & & Public Speaking in Arabic \\
\hline \multirow[b]{2}{*}{6} & \multirow[b]{2}{*}{ Kompetensi Kultural } & \multirow{2}{*}{$\begin{array}{l}\text { Mampu memahami budaya } \\
\text { Arab Islam dalam aktivitas } \\
\text { berbahasa }\end{array}$} & Tafâhum Tsaqâfi (CCU) \\
\hline & & & $\begin{array}{l}\text { Târîkh al-tasqâfah al-'Arabiyyah al- } \\
\text { Islâmiyyah }\end{array}$ \\
\hline \multirow{8}{*}{7} & \multirow{8}{*}{$\begin{array}{l}\text { Lughawiyyat/ } \\
\text { Lisaniyyah }\end{array}$} & \multirow{8}{*}{$\begin{array}{l}\text { Mampu menguasai bidang } \\
\text { kajian bahasa dalam } \\
\text { berbagai aspeknya }\end{array}$} & Falsafat al-Lughah \\
\hline & & & 'ilm al-Lughah al-Âmm \\
\hline & & & 'Ilm al-Lughah al-Nafsi \\
\hline & & & 'Ilm al-Lughah al-Ijtimâ'i \\
\hline & & & 'Ilm al-Lughah al-Tathbîqi \\
\hline & & & 'Ilm al-Lughah al-Nashshi \\
\hline & & & 'Ilm al-Dalâlah \\
\hline & & & Al-Lughah wa al-Manthiq \\
\hline
\end{tabular}

20 'Abdurrahman bin Ibrahim al-Fauzan, et.al., al-Arabiyyah Baina Yadaik, Jilid I, (Riyadh: Maktabah alMalik Fahd al-Wathabiyyah,i 2005), h. Ts. 
Arabiyât Jurnal Pendidikan Bahasa Arab dan Kebahasaaraban, 3 (1), 2016

\begin{tabular}{|c|c|c|c|}
\hline \multirow{9}{*}{8} & \multirow{9}{*}{ Adabiyyat } & \multirow{9}{*}{$\begin{array}{l}\text { Mampu mengapresiasi dan } \\
\text { menguasai bidang kajian } \\
\text { kesastraan dalam berbagai } \\
\text { aspeknya }\end{array}$} & Qawâ'id al-Syi'r wa al-Natsr \\
\hline & & & Nazhariyyat Adabiyyah \\
\hline & & & al-Naqd al-Adabî \\
\hline & & & al-Madzâhib al-Adabiyyah \\
\hline & & & al-Adab al-Muqâran \\
\hline & & & Ilm al-Arûdh \\
\hline & & & Ilm al-Qawâfî \\
\hline & & & 'ilm al-Uslûb \\
\hline & & & Tarikh al-Adab al-'Arabi \\
\hline \multirow{5}{*}{9} & \multirow{5}{*}{$\begin{array}{l}\text { Maharat al-Dirasah } \\
\text { (Study Skill) }\end{array}$} & \multirow{5}{*}{$\begin{array}{l}\text { Mampu melakukan studi } \\
\text { bahasa secara akademik }\end{array}$} & Manhaj al-Bahts al-Lughawi \\
\hline & & & Qirâ'ah Sari'ah wa Fa'alah \\
\hline & & & Kitâbah Maqâlat 'Ilmiyyah \\
\hline & & & Taqdîm Maqâlat wa Muhâdharât \\
\hline & & & I'dâd Muqtarah Bahtsi \\
\hline \multirow{8}{*}{10} & \multirow{8}{*}{$\begin{array}{l}\text { Pembelajaran Bahasa } \\
\text { Arab }\end{array}$} & \multirow{8}{*}{$\begin{array}{l}\text { Mampu membelajarkan } \\
\text { bahasa Arab sesuai standar } \\
\text { yang berlaku }\end{array}$} & $\begin{array}{l}\text { Perencanaan Pembelajaran Bahasa } \\
\text { Arab }\end{array}$ \\
\hline & & & $\begin{array}{l}\text { Pengembangan Kurikulum Bahasa } \\
\text { Arab }\end{array}$ \\
\hline & & & $\begin{array}{l}\text { Pengembangan Silabus dan Materi } \\
\text { Ajar Bahasa Arab }\end{array}$ \\
\hline & & & \begin{tabular}{|l|} 
Strategi dan Metodologi \\
Pembelajaran Bahasa Arab
\end{tabular} \\
\hline & & & $\begin{array}{l}\text { Media \& ICT Pembelajaran Bahasa } \\
\text { Arab }\end{array}$ \\
\hline & & & Evaluasi Pembelajaran Bahasa Arab \\
\hline & & & Pengajaran Mikro Bahasa Arab \\
\hline & & & $\begin{array}{l}\text { Barmajah Ta'lîm Elektroni li } \\
\text { (e-learning) al-Lughah al-'Arabiyyah }\end{array}$ \\
\hline \multirow{6}{*}{11} & \multirow{6}{*}{$\begin{array}{l}\text { Kajian dan } \\
\text { Pengembangan } \\
\text { Pemikiran } \\
\text { Kebahasaaraban }\end{array}$} & \multirow{6}{*}{$\begin{array}{l}\text { Mampu mengkaji dan } \\
\text { mengembangkan pemikiran } \\
\text { seputar kebahasaaraban }\end{array}$} & Ushul al-Nahwi \\
\hline & & & 'Ilm al-Makhtûthât \\
\hline & & & Al-Fikr al-Nahwi \\
\hline & & & Al-Fikr al-Balâghi \\
\hline & & & Al-Fikr al-Adabi \\
\hline & & & Al-I'jaz al-Lughawi \\
\hline & \multirow{10}{*}{$\begin{array}{l}\text { Kajian dan } \\
\text { Pengembangan } \\
\text { Pemikiran } \\
\text { Kebahasaaraban }\end{array}$} & \multirow{10}{*}{$\begin{array}{l}\text { Mampu mengkaji dan } \\
\text { mengembangkan pemikiran } \\
\text { seputar kebahasaaraban }\end{array}$} & Pragmatik Bahasa \\
\hline & & & al-Iqtishâd al-Lughawi \\
\hline & & & Al-Madzâhib al-Nahwiyyah \\
\hline & & & Al-Siyâsah al-Lughawiyyah \\
\hline & & & Lughat al-I'lam wa al-Tijarah \\
\hline & & & Tarjamah Fauriyyah \\
\hline & & & Tarjamah Qânuniyyah \\
\hline & & & Ta'lîm al-Lughah al-Muqâran \\
\hline & & & Al-Majâmi' al-Lughawiyyah \\
\hline & & & Al-Arabiyyah fi Indonesia, dst... \\
\hline
\end{tabular}


Menurut Sukmadinata, ada dua kategori pendekatan $^{21}$ dalam pengembangan kurikulum, yaitu: pendekatan berdasarkan fokus sasaran dan pendekatan berdasarkan sistem pengelolaan. Dari bangunan kurikulum tersebut, dapat ditegaskan bahwa pengembangan kurikulum PBA ke depan dapat mengadaptasi kedua pendekatan tersebut. Strategi pengembangannya adalah perumusan standar kompetensi lulusan (SKL) minimal, penelusuran dan penilaian kebutuhan (calon peserta didik, pengguna lulusan, dan perkembangan dunia kerja), perumusan visi misi Prodi yang mengembangkan kurikulum, dan penataan sistem pengelolaan, baik pada struktur, distribusi, dan pembobotan satuan kredit semester (sks) maupun standarisasi silabus, Satuan Acara Perkuliahan, sampai dengan bahan ajar atau buku daras yang menjadi rujukannya.

Hirarki kompetensi dan mata kuliah yang dapat dikembangkan sebagaimana disebutkan dalam tabel di atas, tentu, bukan diselesaikan dalam satu jenjang, misalnya S1, melainkan dapat dijadikan bahan pengembangan kurikulum program S2 dan S3. Tentu saja, yang perlu ditetapkan kemudian adalah pemilihan, bobot, dan orientasi pengembangannya. Misalnya, program S1 lebih diarahkan kepada (1) pengenalan dan pendasaran ilmu-ilmu bahasa Arab, (2) pemahiran (tamhîr) empat keterampilan bahasa, dan (3) pembentukan sikap dan tradisi akademik-ilmiah dengan dukungan soft skill dan study skill yang memadai, termasuk keterampilan berpikir kreatif. Sementara itu, program S2 diorientasikan kepada: (1) penguasaan konten/substansi keilmuan, (2) pengembangan empat

21 E. Mulyasa, Kurikulum Berbasis Kompetensi: Konsep, Karakteristik, dan Implementasi (Bandung: PT Remaja Rosdakarya, 2006), hal. 66 keterampilan bahasa plus terjemah dan berpikir argumentatif, dan (3) pentradisian meneliti dan menulis buku ajar. Sedangkan Program S3 diarahkan kepada pendalaman, pentakhassusan bidang ilmu tertentu hingga mencapai tingkat kepakaran tertentu, (2) pengembangan kajian pemikiran kebahasaan dan berpikir filosofis-komprehensif; dan (3) pewajiban menulis disertasi yang layak publikasi, bahkan sampai menemukan teori baru atau temuan yang layak di-HaKI-kan (diorientasikan untuk memperoleh hak atas kekayaan intelektual).

\section{Pengembangan Body of Knowledge PBA}

Dalam struktur keilmuan, PBA dapat dilihat dari dua perspektif, yaitu perspektif linguistik dan perspektif pendidikan. Dari perspektif pendidikan, PBA merupakan bagian dari ilmu pendidikan atau aplikasi ilmu pendidikan dalam pembelajaran bahasa Arab. Oleh karena itu, PBA di UIN Jakarta, UIN Yogyakarta, UIN Maliki Malang, dan lainya termasuk salah satu Jurusan di Fakultas Ilmu Tarbiyah dan Keguruan. PBA juga merupakan Jurusan atau Program Studi yang "melibatkan" berbagai disiplin ilmu: linguistik (teoretik dan terapan), pedagogik (pendidikan, kependidikan, dan pembelajaran), psikologi (perkembangan peserta didik), sosiologi, politik, budaya, dan sebagainya.

Dalam pengembangan kurikulum setidak-tidaknya ada empat pendekatan, yaitu pendekatan subjek akademis, pendekatan humanistis, pendekatan teknologis, dan pendekatan rekonstruksi sosial. Pengembangan kurikulum dengan pendekatan subjek akademis didasarkan pada sistematisasi disiplin ilmu masingmasing, karena setiap ilmu memiliki sistematisasi tertentu yang berada dalam 
sistematisasi ilmu lainnya. Pengembangan kurikulum dengan pendekatan ini dilakukan dengan cara menetapkan lebih dahulu mata pelajaran atau mata kuliah yang harus dipelajari peserta didik, yang diperlukan untuk (persiapan) pengembangan disiplin ilmu. ${ }^{22}$

Pendekatan humanistis dalam pengembangan kurikulum bertolak dari ide "memanusiakan manusia". Dalam konteks pendidikan Islam, "memanusiakan manusia" berarti: (1) usaha memberikan kesempatan kepada peserta didik untuk mengembangkan alat-alat potensial dan berbagai potensi dasar (fitrah) seoptimal mungkin untuk dapat difungsikan sebagai sarana bagi pemecahan masalah-masalah hidup dan kehidupan, pengembangan ilmu pengetahuan dan teknologi, budaya manusia, dan pengembangan sikap iman dan takwa kepada Allah Swt; (2) menumbuhkembangkan sifat-sifat ketuhanan (potensi fitrah) itu secara terpadu dan diaktualisasikan dalam kehidupan sehari-hari, baik dalam kehidupan individu maupun sosialnya; (3) membimbing dan mengarahkan manusia agar mampu mengemban amanah dari Allah Swt, sebagai 'abdullah dan khalifatullah di muka bumi. ${ }^{23}$

Pendekatan teknologi dalam pengembangan kurikulum bertolak dari analisis komptensi yang dibutuhkan untuk melaksanakan tugas-tugas tertentu. Materi yang diajarkan, kriteria evaluasi sukses, dan strategi belajarnya ditetapkan sesuai dengan analisis tugas (job analysis). Kurikukulum KBK, misalnya, termasuk kategori pendekatan tekonologis. Desain

22 Muhaimin, Pengembangan Kurikulum Pe didikan Agama Islam, (Jakarta: Rajawali Pers, 2005), h. 140.

23 Muhaimin, Pengembangan Kurikulum ..., h. 159. kurikulum dengan pendekatan ini menekankan pada know how atau caracara menjalankan tugas-tugas tertentu. Sedangkan pendekatan rekonstruksi sosial dalam pengembangan kurikulum bertolak dari problem yang dihadapi masyarakat, untuk selanjutnya dengan memerankan ilmu-ilmu dan teknologi, serta bekerja secara kooperatif dan kolaboratif, akan dicarikan upaya pemecahannya menuju pembentukan masyarakat yang lebih baik. ${ }^{24}$

Oleh karena itu, dengan memadukan keempat pendekatan tersebut, desain pengembangan kurikulum idealnya memperhatikanhirarkidansistematikailmuilmu kebahasaaraban dan kependidikan, mengakomodasi perkembangan peserta didik, menumbuhkembangkan komptensi input sehingga menjadi lulusan yang kompeten (mumpuni), dan tidak melupakan permasalahan dan kebutuhan masyarakat terhadap bahasa Arab. Menurut penulis, jika dirumuskan, maka pengembangan struktur kurikulum PBA dapat digambarkan sebagai berikut.

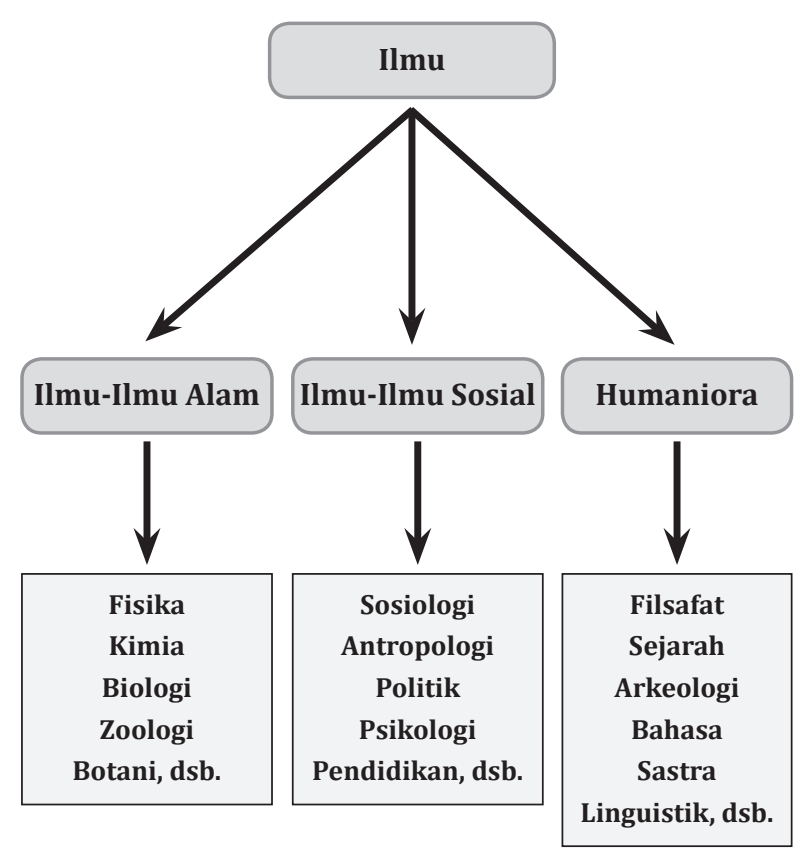

24 Muhaimin, Pengembangan Kurikulum ..., h. 164 dan 173 


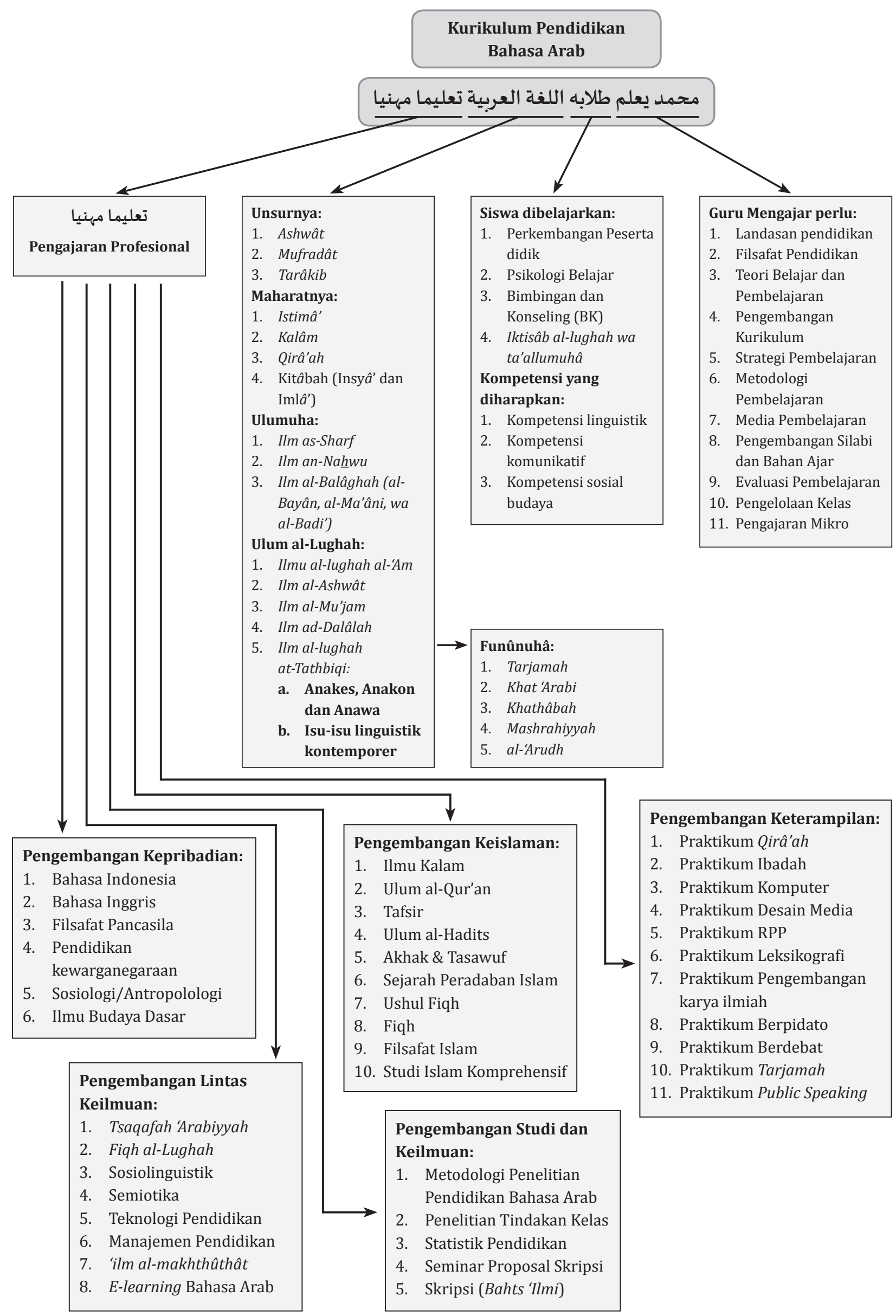




\section{Profil Kompetensi Calon Lulusan PBA}

Berdasarkan asumsi (teoretik) keilmuan, hasil pengamatan (observasi) di berbagai lembaga pendidikan di mana para lulusan PBA mengembangkan karir, dan laporan dari para alumni (baik melalui tracer study dan jejaring sosial), penulis meyakini bahwa calon lulusan PBA itu diproyeksikan memiliki kompetensi sebagai berikut.

\begin{tabular}{|c|c|c|c|}
\hline No. & Profesi Utama & Profesi Alternatif & Keterangan \\
\hline 1 & $\begin{array}{l}\text { Pendidik professional } \\
\text { bahasa Arab }\end{array}$ & |- & $\begin{array}{l}\text { Di Madrasah, Pesantren dan } \\
\text { Sekolah, Lembaga Kursus }\end{array}$ \\
\hline 2 & $\begin{array}{l}\text { Pelatih/Instruktur bahasa } \\
\text { Arab }\end{array}$ & - & $\begin{array}{l}\text { Kegiatan Pelatihan, } \\
\text { workshop, dsb. }\end{array}$ \\
\hline 3 & Peneliti di bidang PBA & - & $\begin{array}{l}\text { Mandiri atau bekerja pada } \\
\text { lembaga pemerintah }\end{array}$ \\
\hline 4 & $\begin{array}{l}\text { Penulis Buku Ajar dan LKS } \\
\text { Bahasa Arab }\end{array}$ & - & \begin{tabular}{|l} 
Mandiri dan bekerjasama \\
dengan lembaga pendidikan
\end{tabular} \\
\hline 5 & Pengembang media PBA & - & $\begin{array}{l}\text { Mandiri dan bekerjasama } \\
\text { dengan lembaga pendidikan }\end{array}$ \\
\hline 6 & $\begin{array}{l}\text { Penerjemah bahasa Arab- } \\
\text { Indonesia dan sebaliknya }\end{array}$ & - & $\begin{array}{l}\text { Mandiri atau bekerjasama } \\
\text { dengan lembaga lain }\end{array}$ \\
\hline 7 & $\begin{array}{l}\text { Penyusun/pengembangan } \\
\text { instrument evaluasi (tes) } \\
\text { bahasa Arab }\end{array}$ & - & $\begin{array}{l}\text { Mandiri atau bekerjasama } \\
\text { dengan lembaga lain }\end{array}$ \\
\hline 8 & Jurnalis (wartawan) & - & Untuk media berbahasa Arab \\
\hline 9 & Dosen PBA & - & Syaratnya: studi lanjut S2 \\
\hline 10 & - & $\begin{array}{l}\text { Desainer website, blog } \\
\text { bahasa Arab }\end{array}$ & $\begin{array}{l}\text { Mandiri atau bekerjasama } \\
\text { dengan lembaga lain }\end{array}$ \\
\hline 11 & - & $\begin{array}{l}\text { Leksikografer (Penyusun } \\
\text { kamus) bahasa Arab }\end{array}$ & $\begin{array}{l}\text { Mandiri atau bekerjasama } \\
\text { dengan lembaga lain }\end{array}$ \\
\hline 12 & - & $\begin{array}{l}\text { Pemandu wisata dari } \\
\text { Timteng }\end{array}$ & $\begin{array}{l}\text { Mandiri atau bekerjasama } \\
\text { dengan lembaga lain }\end{array}$ \\
\hline 13 & - & Penulis artikel tentang PBA & $\begin{array}{l}\text { Mandiri atau bekerjasama } \\
\text { dengan lembaga lain }\end{array}$ \\
\hline 14 & - & Penyiar TV PBA & $\begin{array}{l}\text { Mandiri atau bekerjasama } \\
\text { dengan lembaga lain }\end{array}$ \\
\hline 15 & - & $\begin{array}{l}\text { Kaligrafer, layouter, desainer } \\
\text { grafis berbahasa Arab }\end{array}$ & $\begin{array}{l}\text { Mandiri atau bekerjasama } \\
\text { dengan lembaga lain }\end{array}$ \\
\hline 16 & - & $\begin{array}{l}\text { Wirausahawan yang mahir } \\
\text { berbahasa Arab }\end{array}$ & $\begin{array}{l}\text { Mandiri atau bekerjasama } \\
\text { dengan lembaga lain }\end{array}$ \\
\hline 17 & - & $\begin{array}{l}\text { Diplomat dan pejabat di } \\
\text { lingkungan Kedubes }\end{array}$ & $\begin{array}{l}\text { Berkarir pada lembaga } \\
\text { pemerintah (Kemenlu) }\end{array}$ \\
\hline 18 & - & $\begin{array}{l}\text { Pengusaha di bidang tour \& } \\
\text { travel, termasuk KBIH }\end{array}$ & $\begin{array}{l}\text { Mandiri atau bekerjasama } \\
\text { dengan lembaga lain }\end{array}$ \\
\hline 19 & - & Muballigh, motivator, kiai & $\begin{array}{l}\text { Mandiri atau bekerjasama } \\
\text { dengan lembaga lain }\end{array}$ \\
\hline 20 & & $\begin{array}{l}\text { Sastrawan/kritikus sastra } \\
\text { Arab }\end{array}$ & $\begin{array}{l}\text { Mandiri atau bekerjasama } \\
\text { dengan lembaga lain }\end{array}$ \\
\hline
\end{tabular}


Jangkauan profesiyang bisa ditekunioleh calon lulusan PBA tersebut menunjukkan bahwa kurikulum PBA berbasis KKNI dan SNPT idealnya mengakomodasi dan merespon berbagai tantangan dan peluang yang berkembang dalam masyarakat. Namun, core business (bisnis inti) PBA sebagai penyedia dan pemasok tenaga pendidik professional di bidang bahasa Arab harus tetap menjadi perhatian utamanya.

\section{Strategi Pengembangan \\ Kurikulum Bahasa Arab}

Tantangan dan berbagai persoalan yang dihadapi pendidikan bahasa Arab, termasuk pengembangan kurikulum, tidak mungkin dapat dipecahkan secara personal, tetapi harus melalui pendekatan institusional dan melibatkan banyak pihak (partisipatorissinergis). Namun yang mendesak untuk kita diskusikan secara lebih mendalam adalah pengembangan epistemologi dan kurikulum bahasa Arab pada jurusan Pendidikan bahasa Arab. Yang dimaksud dengan pengembangan epistemologi bahasa Arab adalah pengokohan bangunan keilmuan bahasa Arab agar arah pengembangan pengkajian bahasa Arab lebih dinamis. Dari bangunan epistemologi inilah, struktur keilmuan dan kurikulum tersebut, dapat dikembangkan lebih jauh dalam kurikulum bahasa Arab. Berikut ini adalah beberapa pokok pikiran mengenai model strategi pengembangan kurikulum pembelajaran bahasa Arab ke depan.

Pertama, revitalisasi sinergi ilmu bahasa Arab dan ilmu-ilmu lain yang mempunyai kedekatan bidang kajian, sehingga terjadi proses "take and give" (al-akhdz wa al'athâ') seperti: ilm al-nashsh (tekstologi) ${ }^{25}$,

25 Teun A. van Dijk, 'Ilm al-Nashsh: Madkhal alMutadâkhil al-Ikhtishâshât, terj. dari Textwissenscaft, eine interdiziplinare Einfuhrung oleh Said Hasan Buhairi, (Kairo: Dâr al-Qâhirah, 2002).. 'ilmal-makhthûthât(filologi) ${ }^{26}$,'ilmal-uslûb ${ }^{27}$ (stilistika), ilm al-ta'wîl (hermeneutika), tafsir, dan sebagainya. Dengan demikian, ilmu bahasa Arab tidak hanya menjadi basis studi/kajian, tetapi juga mempunyai "jaringan keilmuan" yang interkoneksi dan multifungsi. Dalam konteks pengembangan kurikulum, pokok-pokok bahasan masingmasing ilmu (baca: mata kuliah) sebaiknya memanfaatkan ilmu-ilmu terkait lainya. Semua dosen pengampu mata kuliah idealnya selalu "bersilaturrahmi keilmuan" satu dengan lainnya, dan boleh juga, agar tidak terjadi kejenuhan, melakukan "tukartambah" pembelajaran mata kuliah.

Kedua, pengembangan cabang-cabang bahasa Arab menjadi ilmu mandiri, seperti: 'ilm al-tarjamah, ilm al-insyâ, ilm ushûl alnahwi, ilm al-Mu'jam (leksikografi) dan sebagainya, sehingga ilmu-ilmu ini tidak hanya sekedar "suplemen", tetapi menjadi ilmu yang lebih substantif, sistematis, dan mendalam. ${ }^{28}$ Seiring dengan semakin

26 Kajian mengenai teks di dunia Arab cukup semarak karena peradaban Islam mewariskan teks yang sangat melimpah. Nashr Hâmid Abû Zayd (1943-sekarang) menyatakan bahwa peradaban Islam adalah peradaban teks (nash). Lihat Nashr Hamid Abû Zayd, Mafhûm al-Nashsh: Dirâsat fi Ulûm al-Qur'ân, (Kairo: al-Hai'ah al-Mishriyyah al-Âmmah li al-Kitâb, 1993), h. 11..

27 Kajian mengenai stilistika pada merupakan bagian dari ilmu balâghah. Seiring dengan perkembangan ilmu bahasa dan sastra Arab, dan estetika (keindahan, termasuk keindahan bahasa), muncullah kajian yang lebih intensif dan mengarah kepada pembentukan ilmu uslûb. Di antara karya yang berkaitan dengan ilmu ini adalah: al-Uslûb: Dirâsah Balâghiyyah Tahliliyyah li Ushûl al- Asâlîb al-Adabiyyah (1993) karya Ahmad al-Syâyib; 'Ilm al-Uslûb: Mabâdi'uhu wa Ijrâ'atuhu (1983) karya Shalâh Fadhl; dan Jamâliyyah al-Uslûb: al-Shûrah al-Fanniyah fi al-Adab al-Arabî karya Fâyiz alDâyah.

28 Tarjamah, misalnya, semula hanya merupakan salah satu cabang bahasa Arab yang "disubordinasikankan" dalam buku-buku pelajaran bahasa Arab. Dalam perkembangannya, tarjamah kemudian menjadi sebuah mata kuliah, dan belakangan menjadi sebuah program studi seperti 
menguatnya basis dan tradisi keilmuan, jika memungkinkan Jurusan Pendidikan Bahasa Arab dapatmembuka program studi atau peminatan: metodologi penelitian bahasa Arab tarjamah Arab-Indonesia, desain media pembelajaran bahasa Arab interaktif, metodologi pembelajaran bahasa Arab, pengembangan kurikulum bahasa Arab, teknologi pendidikan bahasa Arab, 'ilm al-lughah al-tathbîqî' ${ }^{29}$, dan sebagainya.

Ketiga, komparasi, adaptasi, dan improvisasi ilmu bahasa Arab dengan bahasa Inggris dan Perancis yang saat ini lebih maju dan modern. Upaya ini sebetulnya sudah dilakukan, terutama dalam konteks pembagian metodologi pembelajaran bahasa Arab. Namun tokoh-tokoh

yang ada pada Fakultas Adab dan Humaniora. Demikian pula, karya-karya tentang tarjamah mulamula misalnya hanya berupa fann (seni); belakangan kata 'ilm disebutkan secara tegas. Lihat misalnya, Muhammad 'Inâni, Fann al-Tarjamah, (Kairo: alSyarikah al-Mishriyyah al-Âlamiyyah, 1992); Muhammad al-Dîdâwi, 'Ilm al-Tarjamah Baina alNazhariyyah wa al-Tathbîq, (Tunis; Dâr al-Ma'rifah, 1992); Ibrâhîm Badawî al-Jîlânî, 'Ilm al-Tarbiyah wa Fadhl al-'Arabiyyah 'ala al-Lughât, (Kairo: al-Maktab al-'Arabi li al-Ma'ârif, 2000); dan Muhammad alBathal, Fushul fi at-Tarjamah wa at-Ta'rib, (Beirut: Maktabah Lubnan, 2006).

29 Dalam konteks pengembangan pendidikan bahasa Arab, linguistik terapan (applied linguistics) mempunyai posisi sentral. Ilmu ini memberikan perspektif fungsional terhadap masalah-masalah riil dalam pembelajaran bahasa, analisis terhadap persoalan-persoalan kebahasaan berikut pemecahannya. Tammâm menilai ilmu sebagai "basis pengembangan" pembelajaran nahwu maupun bahasa Arab secara umum. Ruang lingkup kajian ilmu ini luas dan sekaligus luwes. Menurut Tammâm, cakupan ilmu ini meliputi: perencanaan bahasa (takhthîth lughawî), bahasa informasi, iklan bisnis, teknologi komunikasi, leksikografi, desain sistem tulisan, penghapusan buta huruf, kritik sastra, analisis psikologis, terapi cacat wicara, geografi dialek, program komputer dan studi bahasa, dan pembelajaran bahasa. Lihat Tammâm, Maqâlât..., Jilid I, h. 82. Bouchouk, Ta'lîm wa Ta'allum al-Lughah al-'Arabiyyah wa Tsaqâfatihâ, (Rabâth: al-Hilâl al'Arabiyyah, 1994), h. 34-35. pengembangnya relatif masih terbatas. Di antaranya adalah Tammâm Hassân, Kamâl Ibrâhîm Badrî, Muhammad Ismâ'îl Shînî, Rusydî Ahmad Thu'aimah, Mahmûd Kâmil al-Nâqah, Rusydî Khâthir, Mahmûd Fahmî Hijâzî, dan 'Abduh al-Râjihî. Semua tokoh tersebut pernah mengenyam pendidikan tinggi di Barat, seperti Amerika, Perancis, Inggris, dan Jerman.

Keempat, revitalisasi pendasaran dan pengaitan pengembangan penelitian bahasa Arab dengan "nuansa Islam" dan sumber utama ajaran Islam, yaitu: Alquran dan alSunnah. Dewasa ini cukup marak dilakukan oleh para sarjana di perguruan tinggi Arab. Beberapa karya yang dapat disebut di sini, antara lain, adalah: al-Isytirâk, al-Lafzhî fi al-Qur'ân al-Karîm Baina al-Nazhariyyah wa al-Tathbîq, al-Tarâduf fi al-Qur'an, alKarîm, Baina al-Nazhariyyah, wa al-Thabîq, al-Tarâduf, fi al-Qur'ân, al-Karîm Baina alNazhariyyah wa al-Tathbîq, ketiganya karya Muhammad Nuruddîn al-Munajjid (1999), al-Nahwu al-Qur'ânî: Qawâ'id wa Syawâhid karya Jamîl Ahmad Dhafr (1998), dan alManhaj al-Islâmî fi al-Naqd al-Adabî karya Sayyid Sayyid 'Abd al-Razzâq (2001).

Kelima, penguatan penelitian dan pendidikan bahasa Arab melalui aplikasi dan improvisasi linguistik modern dan pengalaman positif di bidang pembelajaran bahasa dari Barat dengan tetap mempertahankan kekhususan atau karakteristik ilmu-ilmu bahasa Arab, baik fonologi, morfologi, sintaksis maupun semantik. Upaya ini, antara lain, terlihat dalam beberapa karya seperti: Dirâsat Nahwiyyah wa Dalâliyyah wa Falsafiyyah fi Dhaui al-Lisâniyyah al-Mu'âshirah karya Mâzin Al-Wa'r (2001), al-Dalâlah wa alHarakah: Dirâsah li Af'âl al-Harakah fi Al'Arabiyyah Al-Mu'âshirah fi Ithâr al-Manâhij al-ㅂadîtsah dan al-Dilalah wa al-Kalâm 


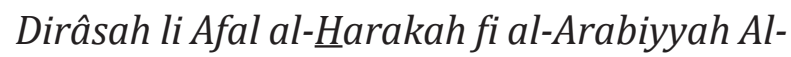
Mu'âshirah fi Ithâr Al-Manâhij al- $\underline{\text { Hadîtsah }}$ keduanya karya Muhammad Muhammad Dâwûd (2002), dan sebagainya.

\section{Simpulan}

Dari uraian dan analisis di atas, dapat ditarik beberapa kesimpulan. Pertama, standarisasi kurikulum Pendidikian Bahasa Arab di lingkungan Perguruan Tinggi Keagamaan Islam Negeri (PTKIN: UIN, IAIN, dan STAIN) penting untuk didesain dan dikembangkan ke arah yang lebih integratifholistik dan humanis. Dengan berbasis KKNI dan SNPT dalam perumusannya, pengembangan kurikulum Pendidikan Bahasa Arab ke depan perlu didasari oleh landasan filosofis dan linguistik mengenai hakikat, karakter dan konsep bahasa Arab, baik sebagai keterampilan maupun sebagai ilmu, landasan psikologis (perbedaan indivisu siswa dan guru yang unik, minat, motivasi belajar, dan sebagainya), landasan sosial budaya, landasan edukasional, dan landasan teknologi dan manajemen pendidikan, sehingga sistem pembelajaran bahasa Arab yang dikembangkan lebih efektif. Aktivitas pembelajaran bahasa (meliputi:Approaches,Syllabuses, Techniques, Exercises $=S A T E)^{30}$ dapat mengantarkan kepada tujuan dan menghasilkan lulusan yang berkompeten, handal, berkualitas, dan profesional.

Kedua, standarisasi pengembangan kurikulum bahasa Arab berbasis KKNI dan SNPT idealnya juga dipandang sebagai multi-sistem terpadu (integrated system), memadukan empat keterampilan bahasa plus keterampilan studi (study skill), ilmu-ilmu bahasa Arab yang relevan

30 Keempat istilah tersebut diadaptasi dari James Dean Brown, The Element of Language Curriculum, (Boston: Heinle \& Heinle Publisher, 1995), h.5. dengan tujuan pengembangan Prodi, dan pemberian pengalaman nyata (tinggal dan berinteraksi dengan komunitas Arab) dalam jangka waktu tertentu, misalnya 1 semester mahasiswa tinggal di salah satu Negara Arab, sambil riset dan menyusun skripsi. Dengan kata lain, kurikulum PBA berbasis KKNI hasil pengembangan harus lebih standar (kerangka kualifikasinya bisa diukur), kontekstual, realistik, fungsional, dan pragmatis (memberi nilai guna bagi pemecahan masalah dan menjawab kebutuhan masyarakat luas).

Ketiga, orientasi pengembangan kurikulum Pendidikan Bahasa Arab di lingkungan PTKIN ke depan idealnya juga merespon tantangan dan tuntutan perkembangan sains dan teknologi. Kompetensi berbahasa Arab produktif belum cukup untuk memiliki daya saing di era globalisasi, melainkan juga perlu keterampilan teknis-profesional dalam bidang ICT. Beberapa kebutuhan baru, akibat tuntutan globalisasi, seperti pemograman pembelajaran bahasa melalui internet, pembuatan $\mathrm{CD}$ pembelajaran bahasa interaktif, e-book interaktif, desain pembelajaran berbasis multikecerdasan, perlu mendapat respon positif dalam pengembangan kurikulum pembelajaran bahasa Arab.

Keempat, untuk mewujudkan semua itu, "silatulilmi" lintas dosen konsorsium, pakar, dankerjasamalintasinstitusipendidikan, dan pihak lain juga menjadi salah satu penentu keberhasilan kita dalam pengembangan kurikulum bahasa Arab. Karena itu, kita memang harus saling berbagi, memberi, dan berkontribusi positif untuk memajukan pembelajaran bahasa Arab di Indonesia masa kini dan mendatang.

Pengembangan kurikulum PBA di lingkungan PTKIN diharapkan dapat 
mencerminkan dan memenuhi visi, misi, tujuan dan sasaran institusi yang berbasis komunitas pesantren dan madrasah ini, sehingga lulusan yang dihasilkan lembaga ini benar-benar berkerangka kualifikasi nasional,mumpuni,profesionaldibidangnya, dan mampu memberi pencerahan bagi umat dan bangsa di masa mendatang.

\section{Daftar Rujukan}

Abdul Wahab, Muhbib, Epistemologi dan Metodologi Pembelajaran Bahasa Arab, Jakarta: UIN Jakarta Press, 2008.

Abdul Wahab, Muhbib, Mawâdd Asâsiyyah li TOAFL, Diktat, Jakarta: Pusat Bahasa, 2008.

Abû Zayd, Nashr Hamid, Mafhûm al-Nashsh: Dirâsat fi Ulûm al-Qur'ân, Kairo: alHai'ah al-Mishriyyah al-Âmmah li alKitâb, 1993.

Abd as-Salam, Musthafa Abd as-Salam, “Tathwîr Manâhij at-Ta'lîm li Talbiyat Mutathallabât at-Tanmiyah wa Muwâjahat Tahaddiyat al-'Awlamah" dalam Prosiding Mu'tamar at-Ta'lim an-Nau'i wa Dawruhu fi at-Tanmiyah alBasyariyyah fi 'Ashr al-'Awlamah, Jami'ah al-Manshûrah Mesir, 2006.

al-Bathal, Muhammad, Fushûl fi at-Tarjamah wa at-Ta'rib, Beirut: Maktabah Lubnan, 2006.

Bousouk, Ta'lîm wa Ta'allum al-Lughah al'Arabiyyah wa Tsaqâfatihâ, Rabâth: alHilâl al-'Arabiyyah, 1994.

Brown, James Dean, The Elementof Language Curriculum, Boston: Heinle \& Heinle Publisher, 1995.

al-Dîdâwi, Muhammad, 'Ilm al-Tarjamah Baina al-Nazhariyyah wa al-Tathbîq, Tunis; Dâr al-Ma'rifah, 1992.

al-Fauzan, 'Abdurrahman bin Ibrahim, et.al., al-'Arabiyyah Baina Yadaik, Jilid I, Riyadh: Maktabah al-Malik Fahd alWathabiyyah,i 2005.

Hassân, Tammâm, al-Lughah al-'Arabiyyah: Ma'nâhâ wa Ma'nâhâ, Kairo: al-Haiah alMishriyyah al-'Ammah li al-Kitâb, 1985.

Hassân, Tammâm, Ijtihâdât Lughawiyyah, Kairo: 'Âlam al-Kutub, 2007

al-Jabburi, 'Imran Jasim dan Hamzah Hasyim as-Sulthani, al-Manâhij wa Tharâ'iq Tadris al-Lughah al-'Arabiyyah, 'Amman: Muassasah Dâr al-Shâdiq asTsaqâfiyyah, 2013.

Kyeong, Yun Eun, "Afdhal Manhaj Ta'lim al-Lughah al-'Arabiyyah li Ghair anNathiqina biha min Wijhat Nazhar 'Ilm al-Lughah al-Ijtima'i”, dalam Journal alUstâdz (Majallah al-Ustâdz), Edisi 201, 2012.

al-Khalifah, Hasan Ja'far, al-Manhaj alMadrasial-Mu'âshir: al-Mafhûm, al-Usus, al-Mukawwinât, al-Tanzhîmat, Riyadh: Maktabah al-Rusyd, 2003.

al-Khûlî, Amîn, Manâhij al-Tajdîd fi al-Nahnwi wa al-Balâghah wa al-Tafsîr wa al-Adab, Kairo: Dâr al-Ma'ârif, Cet. I, 1961.

Muhaimin, Pengembangan Kurikulum Pendidikan Agama Islam, Jakarta: Rajawali Pers, 2005.

Mulham, Sami Muhammad, Manahijal-Bahts fi al-Tarbiyah wa 'Ilm al-Nafs, 'Amman: Dar al-Masirah, 2002.

Mulyasa, E., Kurikulum Berbasis Kompetensi: Konsep, Karakteristik, dan Implementasi Bandung: PT Remaja Rosdakarya, 2006.

al-Musaddî, 'Abd al-Salâm, "al-Lughah al'Arabiyyah wa al-Tahaddiyât al-Jadîdah", diakses dari http://www.alriyadh. com/2005/05/12/article, 30 Juni 2013.

Musthafa 'Abd as-Sami' Muhammad, 
"Dhamanat Tathwîr Manâhij al-Lughah al-'Arabiyyah: Ru'yah Mustaqbaliyyah", dalam Majallah al-Lisân al-Arabi, Edisi 3, 2010.

Richard, Jack, Tathwîr Manâhij Ta'lîm alLughah, Tarjamah al-Kitab min alInjliziyyah ila al-Arabiyyah lada Nashir ibn Abdullah ibn Ghali wa Shalih ibn Nashir as-Syuwairikh, Riyadh: Jami'ah Malik Sa'ud, 2012.

Thu'aimah, Rusydi Ahmad, Manâhij Tadrîs al-Lughah al-Arabiyyah bi al-Ta'lîm alAsâsî, Kairo: Dâr al-Fikr al-Arabi, 2001.

Thu'aimah, Rusydi Ahmad dan Mahmud Kamil an-Naqah, Ta'lîm al-Lughah Ittishâliyyan: Baina al-Manâhij wa alIstirâtijiyyât, Rabath: Mansyûrât Isesco, 2006
Thu'aimah, Rusydi Ahmad, et.al., al-Marji' fi Manâhij Ta'lîm al-Lughah al-'Arabiyyah li an-Nâthiqîn bi Lughât Ukhrâ, Kairo: Dâr al-Fikr al-'Arabî, 2010

van Dijk, Teun A., 'Ilm al-Nashsh: Madkhal al-Mutadâkhil al-Ikhtishâshât, terj. dari Textwissenscaft, eine interdiziplinare Einfuhrung oleh Said Hasan Buhairi, Kairo: Dâr al-Qâhirah, 2002.

Zuhrân, al-Badrâwî, et.al., al-Akhthâ' alLughawiyyah al-Tahrîriyyah li Thullâb al-Mustawa al-Mutaqaddim fi Ma'had al-Lughah al-'Arabiyyah bi Jâmi'ah Umm al-Qurâ, Mekkah: Ma'had al-Lughah al-'Arabiyyah bi Jâmi'ah Umm al-Qurâ, 1986. 